\title{
Innovation Research of University Teaching Management Based on Cultivation of Innovative Talents
}

\author{
Lin lin \\ Institute for Higher Education, \\ Jilin Agricultural University, \\ Changchun, China \\ linlinjlau@126.com \\ $+8615943099007$
}

\begin{abstract}
University teaching management is subject to a variety of factors. The level of its quality directly affects the quality of university teaching and personnel training. The innovation of teaching management is the premise of the implementation of educational innovation. In order to cultivate talents with innovative spirit and practical ability who adapt to the needs of society, we must establish a modern educational concepts and education and management system which adapt to innovative education. By analyzing the necessity of the innovation of university teaching management and the status quo of teaching management, this paper explores the methods of teaching management innovation.
\end{abstract}

Keywords-Innovation; talents cultivation; teaching management

\section{INTRODUCTION}

Innovation is the soul of national progress and an inexhaustible motive force for national prosperity. In 1998, Comrade Jiang Zemin pointed out: "To meet the challenges of scientific and technological advances and the rapid rise of the knowledge economy, the most important thing is to uphold innovation. "The key of innovation in talent, the talent growth depends on education" ${ }^{[1]}$.Therefore, cultivating innovative talents becomes the inescapable and important responsibility of China's education, especially higher education. In "National Medium and Long Term Education Reform and Development Plan (2010 - 2020)”, it is clearly stated that university should update the concept of personnel training and innovate training model, which requires colleges and universities should innovate teaching methods and deepen the reform of school teaching on the basis of following the law of education and the growth of human resources ${ }^{[2]}$. Teaching management possesses the function of planning, organizing, implementing, monitoring and so on to teaching practice. Teaching management reform is an integral part of deepening the reform of school education, which can not only promote the scientificity of school teaching management but also play an important role in the professional growth of innovative teachers and cultivating innovative students.

\section{THE NECESSITY OF THE INNOVATION OF TEACHING MANAGEMENT BASED ON THE CULTIVATION OF INNOVATIVE TALENTS}

The university suffered a lot from the further development of market economy. Therefore, How to get survival and development under the environment of the further development of the market economy becomes a major issue for university.

A. Colleges and universities teaching management innovation is a necessary requirement to adapt to the rapid development of higher education.

In recent years, China's higher education enrollment expands successively and shows a trend in leaps and bounds, which accelerates the pace from elite education to mass education development ${ }^{[3]}$. Thus colleges and universities must implement the innovation of teaching management in order to meet the needs of the rapid development of higher education. Due to the difference of students' level, the multilevel nature and the diversity of the social demand for talent should be increased and flexible teaching management system should be established to adapt to the various needs. Due to the rapid expansion of university scale, scientific, standardized, open teaching management system and management mechanism should be established and the quality of teaching management personnel should be improved as well. Due to the situation that the construction of teaching conditions because of enrollment lags behind the growth rate of students, the innovation and optimization of teaching management should be accelerated and educational resources should be rationally allocated.

\section{B. Colleges and universities teaching management innovation is a necessary requirement to train highly qualified innovative personnel.}

Currently, the competition of various national economy, in fact, is the competition of technology and talent. The development of science and technology depends on the talent and the development of talent depends on education ${ }^{[4]}$. Therefore, the establishment of an advanced teaching management system which is helpful for students to foster 
the spirit of innovation, entrepreneurship and practical ability is the urgent task of current school teaching management innovation. This requires we should break the traditional model of education management and abandon the traditional teaching methods which ignored the development of the students' personality. During the teaching process, we should pay more emphasis on respecting the development of students' personality, guidance, and individualized teaching, and provide more extensive time and space for students' learning, character development and practical activities to cultivate innovative talents to adapt to the needs of society.

\section{Colleges and universities teaching management innovation is a necessary requirement to further deepen the reform of university teaching}

To meet the needs of social development, all colleges and universities increase the intensity of education reform and advance the overall direction and depth. This requires the university teaching management must make the appropriate changes and innovations and work creatively in order to promote the further development of the teaching reform and constantly improve the quality of personnel training. We should establish a teaching management system and operational mechanism which can adapt to the socialist market economic system, fully mobilize the enthusiasm of teachers and students in teaching and learning, and promote the rapid development of university.

\section{ANALYSIS ON THE CURRENT SITUATION OF TEACHING MANAGEMENT BASED ON THE CULTIVATION OF INNOVATIVE TALENTS}

There are many deficiencies in China's current management of university teaching, which cannot meet the requirements of university talent training proposed by the development of age. These deficiencies are mainly as follows:

\section{A. Backward management philosophy}

Personnel training of the new era requires university must have a teaching management team that possesses strong operational capacity and high-quality. However, in practice, the teaching management team is relatively weak and lacks general management theory and methods and the teaching management concepts are also slow. The transfer of knowledge is still regarded as the most important task of universities, which results in ignoring training students' ability to solve problems. In teaching management, the emphasis on students' subjectivity and independence is not enough. Besides, teaching management staff lack awareness of service and advanced management ideas. They also don't realize the importance of the cultivation of creative talents, which restricts the cultivation of innovative talents to some extent.

\section{B. Unitary and rigid professional set}

Teaching plan, curriculum, professional choice have great impact on the cultivation of innovative talents. The higher education system in our country is divided too detailed on the professional setting and the curriculum is also too narrow, which are not conducive to cross-disciplinary and improving students' knowledge structures ${ }^{[5]}$. In addition, some proportion of the curriculum's structure is unbalanced and there are too many theoretical courses and too few skills courses. And most students lack the awareness of their profession, hobbies, and strengths before going to college, which is not conducive to the cultivation of talents.

\section{Unilateral evaluation of teaching content}

The assessment methods of most courses in colleges and universities are mainly in the form of final exam. This kind of assessment method only focuses on the final scores and ignores students' usual performance, which cannot truly assess students learning. The assessment method is unilateral and most content is limited to the memorizing and theoretical knowledge delegated by teachers in classroom. This assessment method can only reflect students 'readiness for the exam and does not reflect the true ability of students and severely restricts the cultivation of students' innovative ability.

\section{Unilateral teaching management methods}

Currently, many colleges and universities' teaching management methods can still not meet the needs of teaching operation and personnel training. Academic teaching management system function is not perfect, resulting in students unable to timely and accurately understand the relevant information. In addition, modern information technologies such as computer-assisted instruction, online teaching, multimedia teaching, are not well applied in teaching activities. Students cannot choose their own way of learning according to their own interests and hobbies. All these factors severely restrict the cultivation of innovative talents.

\section{EXPLORATION ON THE PATH OF TEACHING MANAGEMENT INNOVATION BASED ON THE CULTIVATION OF INNOVATIVE TALENTS}

\section{A. Innovate teaching management concepts and determine the "people-oriented" concept}

During the process of university teaching management innovation, concept is the pilot and guide to action. We should innovate teaching management philosophy and firmly establish a comprehensive development perspective, the concept of all-taught, the concept of multivariate human quality and the concept of system-cultured ${ }^{[6]}$. The main body of teaching practice innovation is teachers and students. In practical teaching management, we should base on teacher-centered, student-centered and regard achieving and maintaining the real and fundamental interests of the majority of faculty and students as the most fundamental 
starting point and ending point of all management systems and management practices. We should implement democratic management at work, respect the fundamental rights of teachers and students, establish the concept that management is service, and solve the problems for teachers and students enthusiastically and initiatively. We should also welcome teachers and students to participate in the school teaching management, respect the views and suggestions of teachers and students, increase feelings of ownership of teachers and students, so as to stimulate the teacher's enthusiasm, initiative and creativity.

\section{B. Strengthen the teaching management capabilities and lead the teaching reform}

Pay attention to and highlight the functions of teaching guidance, construct teaching guidance operation mechanism, and promote the teaching management innovation. Construct specialized organizations of teaching reform and engage in the leading functions of education reform. Organizing experts of teaching managers analyze various teaching reform documents of state and the local, combine with the actual situation of their own school's professions, propose the specific programs of teaching reform and the training model of innovative talents, and form the quality projects of their own. Under the support of specialized funds, the teaching management institutions of the college's second rank organize teachers to implement quality engineering solutions and enhance process management, guidance. Organize teachers and experts to summarize and identify the outcomes of the school quality project. By means of publicity and training, teaching managers should help teachers and students develop a healthy teaching culture, lead the development of teaching culture, and promote teachers and students to establish the correct values and outlook on life.

\section{Adapt to the needs of innovation and establish flexible teaching management system}

Scientific and coherent university teaching management system of clear responsibility and rights is essential to ensure the university management reform and innovation. Perfect credit system management. Colleges and universities should actively innovate personnel training programs, optimize curriculum structure, increase the number of elective courses, and expand the scope of student enrollment. Be responsible for mentor appointment, regulate the content of mentoring, and promote the effectiveness of the guidance of mentors for students ${ }^{[7]}$. Through the system of Enrollment, profession shifting, the second degree, minor system and other professional selection system, we should expand students' needs to different professions and promote the matching of student's personality, interests, and job with their professions. Innovate teaching evaluation system. In the specific evaluation, we will adopt the multiple evaluation methods by combining the qualitative and quantitative evaluation, combining student evaluation, peer evaluation and professor evaluation, combining process evaluation and outcome evaluation in order to avoid the drawbacks of bureaucracy and unilateral value and deduct the worries of teacher reform $^{[8]}$.

\section{Strengthen the building of teaching management team and establish a specialized system of teaching management}

Confirm teaching management is a kind of work with specialized knowledge structure and skills. Establish the vocational training, access, assessment, promotion and elimination mechanism about teaching management. Strengthen professional training to acquire more knowledge and skills and constantly improve themselves. Establish a multi-level performance evaluation mechanism. Combine work performance with salary cut, job title promotion, and distribution of rewards. Clear rewards and punishments can create a healthy competition situation ${ }^{[9]}$. Teaching management staff who have made outstanding contributions including proposing positive and meaningful suggestions and comments and innovating ways of working to improve the efficiency should be rewarded, which can enhance the self-efficacy of teaching managers and establish a stable high level of motivation and activate their initiative ${ }^{[10]}$.

\section{E. Using teaching management informatization to promote teaching modernization}

Using teaching management informatization to promote teaching modernization and promoting change and innovation of teaching are effective ways to solve the current problem of universities. Colleges and universities should integrate software and hardware resources and put teaching management information systems into the overall information technology planning in the school. Realize resource unified position and promote sustainable development of teaching management. Improve service levels of teaching management. Relying on information technology, expand the scope of informatization and realize the digitization of curriculum, profession, teaching and research, innovative personnel training, teaching quality monitoring, and practice of education. Construct digital educational resources of high-quality, sharing environment, student growth record, and comprehensive quality evaluation system.

\section{ACKNOWLEDGMENT}

This paper is the major research of higher education's $t$ eaching study of Jilin Province in2014:the local agricultural colleges stick to the stage outcomes of the research and prac tice of "school management is teacher oriented and teaching is student oriented" .

\section{REFERENCES}

[1] Jiang Zemin. Speech with Technology Sector in Science City of Siberia [N] People's Daily, 1998-11-25. 
[2] Wang Junsheng. Problems in and Reform Measures for University Teaching Management Under the Perspective of Innovation [J] Higher Agricultural Education, 2012-11-11:52-54

[3] Zhou Ling. On the Construction of Quality Assurance System of Higher Education of China on the Background of Popularization [J] Times Education, 2014(17):23

[4] Yu Fuling. Research on the Construction of Students Research and Service System Based on Innovative Talents Cultivation [J]. Course Education Research, 2014 (30) : 100.

[5] Wang Minhua. Start Complex Course and Optimize Curriculum Setting [J] Modern Enterprise Education, 2013 (24) : 436-437.

[6] Chen Hao. Critical Comments on Higher Education [M] Hangzhou: Zhejiang University Press,2011

[7] Shi Jinlian. Research on Construction of Universities Teaching Management System Based on Innovative Talents Cultivation [J]. Press of Changchun University of Science and Technology, 2013(12):162-164

[8] Fan Shouxin. Thinking of China's Teaching Method Reform--------Taking the Research Teaching Reform as An Example [J] Higher Agricultural Education, 2011, (8) : $27-30$

[9] Wang Junshen. Problems Analysis and Countermeasures for Public Elective Teaching and Management Under the Perspective of Motivation [J] Journal of Yangzhou University: Higher Education Study Edition, 2011, (6): 37-40

[10] Yin Gang. Research on Management Countermeasures of Higher Education Based on Innovative Talents Cultivation [J] University Education, 2013 (10): 155-156 